\title{
A arte fotográfica de Pierre Verger: a decolonialidade na cultura afro-brasileira como território de resistência na Bahia
}

Pierre Verger's photographic art: the decoloniality of Afro-Brazilian culture as a territory of resistance in Bahia

El arte fotográfico de Pierre Verger: la descolonialidad en la cultura afrobrasileña como territorio de resistencia en Bahía

Mariana Brazil Nunes ${ }^{1}$

1 Tem graduação em Licenciatura em Desenho e PI Federal da Bahia (2010), Especialização em Desenvc Transtornos (2012) e Mestrado em Artes Visuais pela professora de Artes na educação infantil e fundameı Salvador e Lauro de Freitas, Bahia. Atualmente é pro no Ensino Médio da rede pública do Estado da Bahia. de arte-educação, com ênfase em Artes Plásticas, atu seguintes temas: Processos de ensino/aprendizager artísticas e Identidade cultural. 


\title{
Resumo
}

Este trabalho trata de uma abordagem sobre a arte fotográfica de Pierre Verger focalizada no seu olhar sobre a cultura afro-brasileira na Bahia. Discute-se aqui o olhar etnográfico de Verger direcionado para a população afro-brasileira, trazendo uma linguagem de interseção entre a fotografia e a etnologia. As imagens que traduzem o recorte do sincretismo religioso nos rituais do Candomblé são entendidas como uma linguagem visual própria e não limitado à um simples documentário. Entendese as imagens como uma das formas de manifestação da arte afro-brasileira a qual representa uma estratégia de resistência dos escravos africanos na Bahia, através de seus elementos culturais vindos de um regime servil, com valores que emergiram no novo ambiente. Pretende-se, assim, contribuir para o conhecimento da interface entre a identidade cultural/ancestralidade afrodescendente e a arte das fotografias de Verger, na perspectiva do processo de fortalecimento da identidade cultural da comunidade afrodescendente na Bahia.

\section{Palavras-chave}

Verger, identidade cultural, sincretismo

\begin{abstract}
We herein bring an approach to Pierre Verger's photographic art focused on his view of Afro-Brazilian culture in Bahia. We discuss here Verger's ethnographic looked forward at the Afro-Brazilian population, which brings a language of intersection between photography and ethnology. The images that reflect the cutout of religious syncretism in Candomble rituals are understood as an own visual language, not limited to a simple documentary. Images are understood as one of the forms of manifestation of Afro-Brazilian art which represents a strategy of resistance by African slaves in Bahia, through its cultural elements coming from a servile regime, with values that emerged in the new environment. It is intended, therefore, to contribute to the knowledge of the interface between cultural identity / Afro-descendant ancestry and the art of Verger's photographs, in the perspective of the process of strengthening the cultural identity of the Afro-descendant community in Bahia.
\end{abstract}

\section{Key words}

Verger, cultural identity, syncretism

\section{Resumen}

Es un acercamiento al arte fotográfica de Pierre Verger centrada en su visión de la cultura afrobrasileña en Bahía. Discutimos aquí la mirada etnográfica de Verger a la población afrobrasileña, que trae un lenguaje de intersección entre fotografía y etnología. Las imágenes que reflejan el recorte del sincretismo religioso en los rituales del Candomblé se entienden como un lenguaje visual propio y no se limitan a un simple documental. Las imágenes se entienden como una de las formas de manifestación del arte afrobrasileño que representa una estrategia de resistencia de los esclavos africanos en Bahía, a través de sus elementos culturales provenientes de un régimen servil, con valores surgidos en el nuevo entorno. Se pretende, por tanto, contribuir al conocimiento de la interfaz entre identidad cultural / ascendencia afrodescendiente y el arte de la fotografía de Verger, en la perspectiva del proceso de fortalecimiento de la identidad cultural de la comunidad afrodescendiente en Bahía.

\section{Palabras-Clave}

Verger, identidad cultural, sincretismo

ISSN: 2447-1267 
O processo de colonização portuguesa em terras brasileiras durou da primeira metade do século XVI até a primeira metade do século XIX. Em meados do século $\mathrm{XVI}$, quando o açúcar de cana tornou-se o mais importante produto de exportação da colônia, os portugueses deram início à importação de escravos africanos, comprados nos mercados escravistas da África ocidental e trazidos inicialmente, para lidar com a crescente demanda internacional do produto, durante o chamado Ciclo do Açúcar (TAVARES, 2001, p.52). O tráfico negreiro atlântico, também identificado como diáspora negra africana, foi a maior migração forçada da história da humanidade. Aproximadamente 12 milhões de africanos foram embarcados, cerca de 11 milhões chegaram às Américas e 40\% deles vieram para o Brasil (quase 5 milhões) ${ }^{1}$ (GOMES, 2019 , p.19, 24). Laurentino Gomes (2019) considera que a escravidão no Brasil foi uma tragédia de proporções gigantescas, com impacto profundo na cultura e no sistema político que deu origem ao país após a independência, em 1822: [...] "Nenhum outro assunto é tão importante e tão definidor para a construção da nossa identidade". (GOMES, 2019, p.34)

Os estudos historiográficos mostram que desde a abolição da escravatura no Brasil em 1888, passando pelo período republicano até os dias atuais, o que a população negra vivenciou foi a consolidação de projetos sócio-políticos excludentes. A ideia de raça se fortaleceu como critério de classificação social e de justificativa para a desigualdade, embora a Constituição determinasse que todos os cidadãos fossem iguais perante a lei (DANTAS, 2012, p. 88). Não à toa o pernambucano abolicionista Joaquim Nabuco dizia, às vésperas da proclamação da República, em 1889: [...] "A grande questão da democracia brasileira não é a monarquia, é a escravidão" (GOMES, 2019, p.33), frase que poderia ser dita com propriedade nos dias atuais.

O fenômeno da diáspora negra africana fez surgir uma cultura de relações interterritoriais desses dois continentes que se conectaram através de relações desiguais de processos de domínio e resistência. Durante esses processos, os milhões de africanos aqui aportados e seus descendentes não apenas contribuíram para o desenvolvimento econômico das colônias, produzindo riquezas com seu trabalho escravizado não remunerado, como também trouxeram riquezas culturais e aí desenvolveram outras, através de uma resistência que continua até hoje (MUNANGA, 2018, p.114). Exemplo disso são as diversas formas de manifestação da arte afrobrasileira inevitavelmente plenas de elementos de origem africana, como os rituais do candomblé na Bahia, com suas danças, cantos e ritmos de percussão. Formas essas que traduzem a identidade cultural do povo africano já retratadas por muitos artistas e sob diversos olhares. $\mathrm{Na}$ arte afro-brasileira os elementos culturais africanos vindos de um regime servil com valores que emergiram no novo ambiente de(s)colonializado² além $^{2}$ da proibição da prática da sua religião/conversão ao catolicismo, são configurados

1 O banco de dados Slave Voyages (www.slavevoyages.org) cataloga cerca de 36.000 viagens dos navios negreiros ao longo de 3 séculos e meio (Gomes, 2019, p. 18).

2 Não há consenso quanto ao uso do conceito decolonial/descolonial. Ambas as formas se referem à dissolução das estruturas de dominação e exploração configuradas pela colonialidade e ao desmantelamento de seus principais dispositivos. Aníbal Quijano, entre outros, prefere referir-se à descolonialidad, enquanto a maior parte dos autores utiliza a ideia de decolonialidad (QUINTERO et al, 2019, p.5) . 
como estratégias de resistência. Ao se observar os elementos estruturais, culturais e sociológicos da religião católica percebem-se semelhanças aos elementos culturais africanos, bem como a sua manipulação como uma das formas de manifestação para a proteção de suas crenças ancestrais (MUNANGA, 2018, p.116).

A arte como território de resistência não trata somente de uma questão de negar um poder opressor, mas também de criar maneiras de existir, o que inclui formas de sentir, de pensar, e de atuar em um mundo que está sendo construído através de variadas insurgências e irrupções, na busca de um mundo humano. $O$ tema da re-existência é um tema crucial nos estudos da decolonialidade, como parte da pedagogia e da estética decolonial. A re-existência é uma irrupção que envolve o pensamento, a ação, o sentir e a percepção (MALDONADO-TORRES, 2017).

A concepção de identidade cultural continua sendo uma força muito criativa e poderosa em formas emergentes de representação entre povos ainda marginalizados. Nas sociedades pós-coloniais a redescoberta dessa identidade, em geral, promove novas formas de representação visual (HALL, 1989, p. 69). A fotografia é uma delas. Como linguagem artística, a fotografia pode expressar sentimentos e pensamentos que contribuem enquanto instrumento capaz de perpetuar e imortalizar momentos; um meio de desenvolver o olhar e a criatividade, de maneira a estimular a problematização e o debate para integrar grupos, aguçar a visão e a percepção de mundo. $O$ fotógrafo se comunica por imagens visuais, assim como os escritores o fazem com as imagens inventadas pelas palavras (WOLFENSON, 2009, p. 38). Na visão da escritora americana Susan Sontag (1933-2004) a função da arte fotográfica como documento cultural é atribuída à importância das fotografias que aconteceram em outra época: [...] imagens que mobilizam a consciência estão sempre ligadas a determinadas situações históricas (SONTAG, 2004, p. 27). A autora refere que há um código visual pelo olhar fotográfico que traz a fotografia como experiência capturada. É a fotografia como a ética do ver. As imagens formam um sistema de representações e de significações especificamente caracterizado por veicular uma informação visual, um registro da aparência visível do mundo [...] "O olhar se transforma em linguagem, ou seja, o visível em legível" (SOUTY, 2008, p. 219).

Fotógrafos que fizeram trabalhos puramente documentais e jornalísticos tornaram-se ícones da arte fotográfica, como o francês Cartier-Bresson, o húngaro naturalizado americano Robert Capa e o brasileiro Sebastião Salgado. No Brasil, os fotógrafos franceses Pierre Verger e Marcel Gautherot tornaram-se expoentes na arte fotográfica em um período conturbado pela Segunda Guerra Mundial. Ambos vieram direcionados pela obra de Jorge Amado publicada na França, ambos tiveram suas obras expostas e publicadas no mundo e ambos alcançaram enorme notoriedade. Mas somente Verger adentrou-se totalmente na cultura afro-brasileira da Bahia, a pessoa do negro como protagonista, tornando-se uma figura importante e participante nos ritos do candomblé (WOLFENSON, 2009, p. 35,36).

Verger chegou como fotógrafo e transformou-se em um observador etnográfico, antropólogo, historiador e botânico. Sem dúvida, foi um dos grandes pesquisadores da cultura e religião afro-brasileiras e deixou uma vasta obra, resultado de suas 
inúmeras pesquisas (LÜHNING, 1998-1999, p. 315).

Nesse artigo pretende-se contribuir para o debate étnico-racial através das imagens da obra de Verger, revisitadas e abordadas na perspectiva da arte afrodiaspórica como forma de compreender a (re)construção da identidade cultural afrodescendente.

\section{A arte afro-brasileira como território de resistência: o sincretismo religioso na Bahia}

Segundo Munanga (2018), os antepassados africanos brasileiros de hoje são oriundos de várias sociedades africanas, ou seja, de um pluralismo étnico-linguístico. Porém, ao serem transportados para cá, não viveram etnicamente separados como em suas terras de origem, e sim submetidos juntos ao trabalho escravizado. Na Bahia, a importação de escravos africanos começou em seguida ao estabelecimento dos primeiros engenhos de açúcar, próximo a 1550 e por quase 100 anos foi o trabalho escravo a base da economia da província: [...] "Aqui vieram africanos que pertenciam às mais diferentes nações, as mais conhecidas devido às linguagens iorubas, ewes, jejes, fulas, tapas, aussás (malês), ardas e calabares." (TAVARES, 2001, p.55)

Não havia outra forma de sobrevivência que não a de se aculturarem em uma única cultura, que pode ser chamada africanidade e está na música, na dança, nas religiões de matrizes africanas, e/ou nas artes visuais, essas últimas chamadas de artes afro-brasileiras (MUNANGA, 2018, p. 604-605). Munanga (2018) chama a atenção para o fato de que a conversão dos africanos à religião católica no século XVI era muito conveniente, estava entre os motivos para legitimar e justificar a escravidão. Havia, inclusive, a bordo dos navios, capelas para serem batizados antes mesmo de fazerem a travessia do Atlântico e ao chegarem ao Brasil eram proibidos de praticar suas religiões (MUNANGA, 2018, p.115). A religião católica era considerada única e verdadeira e as dos escravizados apenas cultos misteriosos ou simples superstições e a festa do candomblé com suas danças, cantos e ritmos de percussão não eram vistos como religião e sim, como divertimento de negros nostálgicos. Especialmente na Bahia o sincretismo religioso decorreu da fusão dessas duas crenças religiosas: o Cristianismo (predominante entre os Portugueses) e o Candomblé (predominante entre as nações africanas escravizadas no Brasil).

Como a etimologia sugere, o sincretismo (forma jônica de sugkratos = misturado junto) foi usado inicialmente para descrever uma situação política. Entretanto, o uso quase exclusivo de sincretismo no campo do pensamento religioso ganhou impulso no século XIX. A apropriação restrita do termo pela teologia pode ter se desenvolvido do fato de que, na Antiguidade, tanto para os cretenses quanto para outros povos mediterrâneos, o discurso político era frequentemente inseparável do discurso religioso (GATTI, 2016, p. 66). Segundo Gatti (2016) o sincretismo é uma forma de dialogismo no contexto de uma cultura, pode ser definido como um tipo 
de articulação na qual os elementos se engajam numa relação dialógica dentro de um mesmo campo discursivo ou entre campos discursivos diferentes. Uma das características que distinguiram as relações sincréticas de outras formas de relação é que os elementos envolvidos interagem, dialogam e estabelecem relações de poder específicas na forma de alinhamentos (frequentemente antagonísticos) e, mesmo assim, mantêm suas identidades distintas (GATTI, 2016, p.64).

Assim era, e ainda é o Candomblé: um conjunto de cerimônias religiosas animistas que diferem nos rituais étnicos, conforme seja ijexá, ewe (jeje), aussá, kêtu, cabinda, congo. Os rituais em formato de festa envolvem o sacrifício de animais em homenagem aos orixás, danças e cantos ao som dos tambores/atabaques, agogôs, adjás e xerês (TAVARES, 2001, p.59).

Graças a falta de entendimento pelos colonizadores, foi possível aos escravizados manipular sincreticamente as similitudes fundamentais entre as duas religiões como estratégia de resistência e de sobrevivência. Assim, na teologia católica a relação de intercessão dos santos junto à Virgem Maria e desta junto à Jesus é semelhante à cosmologia iorubá, na qual os orixás intercedem pelos homens junto à Olorum. Do mesmo modo que cada santo tem uma responsabilidade no atendimento e na proteção aos humanos, também nas religiões negro-africanas os voduns e os orixás. Essas correlações baseiam-se, em geral, em semelhanças funcionais. É no contexto dessa correspondência entre santos católicos e orixás que situa-se a continuidade das formas artísticas plásticas africanas e o surgimento de uma linguagem plástica afrobrasileira, como no caso de Exú (que assumiu novos significados e novas funções) (MUNANGA, 2018, p.116).

\section{O preto e branco: a questão identitária}

A identidade cultural dos afrodescendentes brasileiros passa pela própria definição de negro. Como refere o antropólogo Kabengele Munanga (2004), o Brasil é um país onde existem [...] pessoas negras que introjetaram o ideal de branqueamento, que não se consideram como negras, de maneira a tornarem o processo de construção/resgate identitário um processo doloroso. Segundo o autor, os conceitos de negro e de branco têm um fundamento etno-semântico, político e ideológico, mas não biológico. As novas tecnologias da genética molecular evidenciam que muitos brasileiros aparentemente brancos trazem marcadores genéticos africanos, ou seja, cada um pode se dizer um afrodescendente. E o mesmo sucederia com afrodescendentes que têm marcadores genéticos europeus, porque muitos de nossos mestiços são eurodescendentes. Portanto, questionar essa identidade passa a ser menos importante do que questionar o lugar ocupado coletivamente por esses descendentes de africanos em um universo atravessado por práticas racistas, e também questionar o espaço ocupado por essas culturas e a história de seus produtores no sistema educativo brasileiro dominado pelo eurocentrismo (MUNANGA, 2004, p. 52). 
As identidades culturais refletem experiências históricas e códigos culturais em comum que dão um sentido de unicidade, as quais tiveram um papel predominante nas lutas pós-coloniais (HALL,1989, p 69). A concepção de identidade cultural continua sendo uma força muito criativa e poderosa em formas emergentes de representação entre povos ainda marginalizados. Nas sociedades pós-coloniais a redescoberta dessa identidade, em geral, promove novas formas de representação visual e cinematográfica.

\section{A obra fotográfica de Verger e o sincretismo religioso na Bahia}

Pierre Edouard Leopold Verger (1902-1996), conhecido como Pierre Fatumbi Verger, fotógrafo e etnólogo autodidata franco-brasileiro viveu em Salvador, Bahia, durante quase 60 anos. Seus textos e fotos foram publicados em mais de 100 livros (Fundação Pierre Verger - http://www.pierreverger.org/br/). Verger construiu, através de suas fotografias, uma imagem positiva do negro direcionada para a população afro-brasileira, trazendo uma linguagem de interseção entre a fotografia e a etnologia (MARTINI, 1999, p.7). Exemplo disso é o livro "Orixás, Deuses lorubás na África e no Novo Mundo", em sua nova edição (2018) com fotos inéditas e um prefácio assinado por Mãe Stella de Oxóssi, lalorixá do Axé Opô Afonjá. O livro é fruto das constantes viagens de Pierre Verger à África entre os anos de 1948 e 1965 e apresenta textos e ilustrações que comentam e mostram aspectos do culto aos orixás, deuses dos iorubás, em seus lugares de origem, na África (Nigéria, antes Daomé e Togo) e no Novo Mundo (Brasil e Antilhas). Em suas publicações Verger dá, através de uma abordagem histórica, as razões para a existência, sobrevivência e força das religiões afro-brasileiras no Brasil, incluindo todas as nações africanas. É importante ressaltar que praticamente toda a obra escrita de Verger (excluindo as publicações de álbuns e livros fotográficos) refere-se ao contexto da cultura iorubá, tanto na Nigéria e no Benin (África) quanto na diáspora nas Américas (LUHNING, 1998-1999, p. 325). A sua publicação Syncrétisme (Paris, 1983) aborda o sincretismo religioso com diversas fotos, em sua dimensão histórica, com possíveis hipóteses para o seu surgimento. A mesma questão aparece também no centro da publicação "African cultural survivals in the New World: the examples of Brazil and Cuba" (Lagos, Nigéria,1978) (LUHNING, 1998-1999, p 335). Também é importante ressaltar que todas as suas fotos são em preto e branco $(P \& B)$ e tons cinza, mesmo já existindo a técnica de fotos coloridas, o que caracteriza a sua obra.

Em resenha publicada em 2014, Isabela Gaglianone comenta o único livro autobiográfico de Pierre Verger "50 anos de fotografia 1932-1982" (1988) reeditado pela Fundação Pierre Verger em 2011. A autora comenta que o trabalho fotográfico historiográfico de Verger é desenvolvido através de uma linguagem própria e com um espírito inconfundível, não limitado a um simples documentário. São ali registrados acontecimentos culturais sob uma poética que traduz uma serena intimidade com o mundo. São imagens líricas, que encerram em si um tempo articulador do entendimento 
humano com a natureza das coisas, o tempo do olhar, do andar, pedalar, navegar: um tempo que se dá tempo de ser, a essência do ser cultural. As imagens de Verger são vistas pela autora como humanamente tocantes, registrando os homens e o Homem, as culturas e a humanidade. Ela enfatiza a dignidade que seus enquadramentos conferem aos retratados e às culturas que eles representam e encarnam, mostrando que neles é que se concentra grande parte de seu valor antropológico. São fotos fortes, sensoriais, ricas em nuances de texturas e sombras, de múltiplas matizes, que trabalham na formação do pathos do trabalho, tornando nele, a representação da natureza humana tangível e profunda (GAGLIANONE, 2014).

Consideramos que o olhar etnográfico de Verger, sua admiração pelo ser humano negro e pela cultura africana, transformou sua obra fotográfica em uma representação ímpar da identidade cultural afro-brasileira. Nessa representação é possível visualizar a linguagem plástica das suas imagens com distintos elementos culturais africanos, entre os quais aqueles que representam o culto aos deuses africanos (Figura 1) ${ }^{3}$.

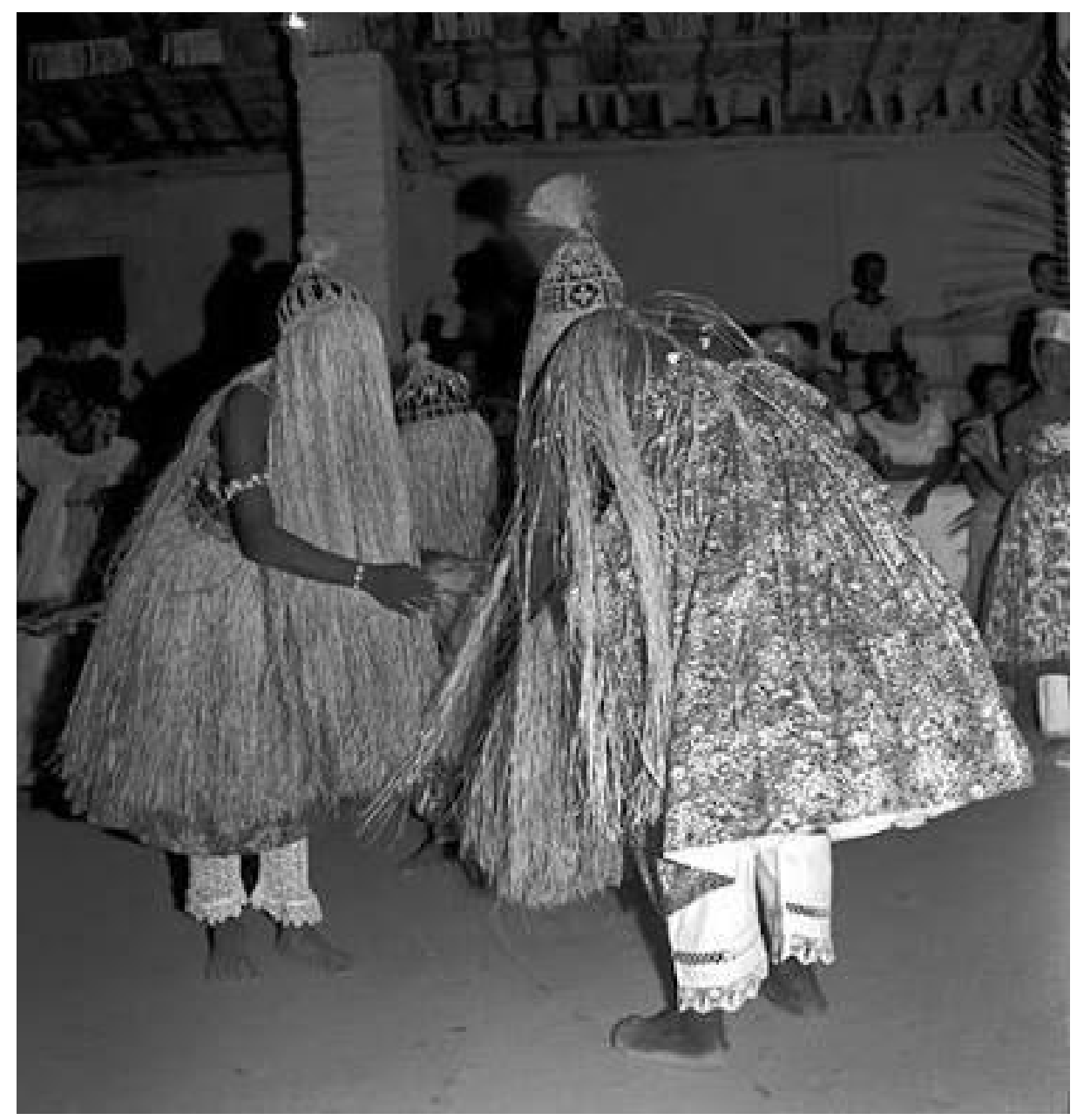

Fig. 1 - Pessoas em transe de Obaluayê, Omolu - Candomblé Joãozinho da Gomea, Salvador, Brasil, 1946 - FPV 27374 - Foto Pierre Verger @ Fundação Pierre Verger. 
Em um recorte das suas imagens direcionadas ao culto do candomblé (tanto em África, quanto no Brasil), Verger veicula uma informação visual significativamente expressiva, talvez porque além de fotógrafo ele convergia à essa habilidade a sua personalidade investigativa e literária. As imagens do culto do candomblé baiano que representam o sincretismo religioso católico(europeu)-candomblé(africano) (Figura 2) indicam um processo não só de resistência, mas de construção e de subversão da ordem estabelecida desde o período colonial, e que perdura no pós-colonial do Brasil. Referem-se, portanto, aos [...] "processos mediante os quais quem não aceita ser dominado e controlado, não só trabalha para desprender-se da colonialidade, mas também para construir organizações sociais não manejáveis e controláveis por essa matriz" (GÓMEZ e MIGNOLO, 2012, p.8).

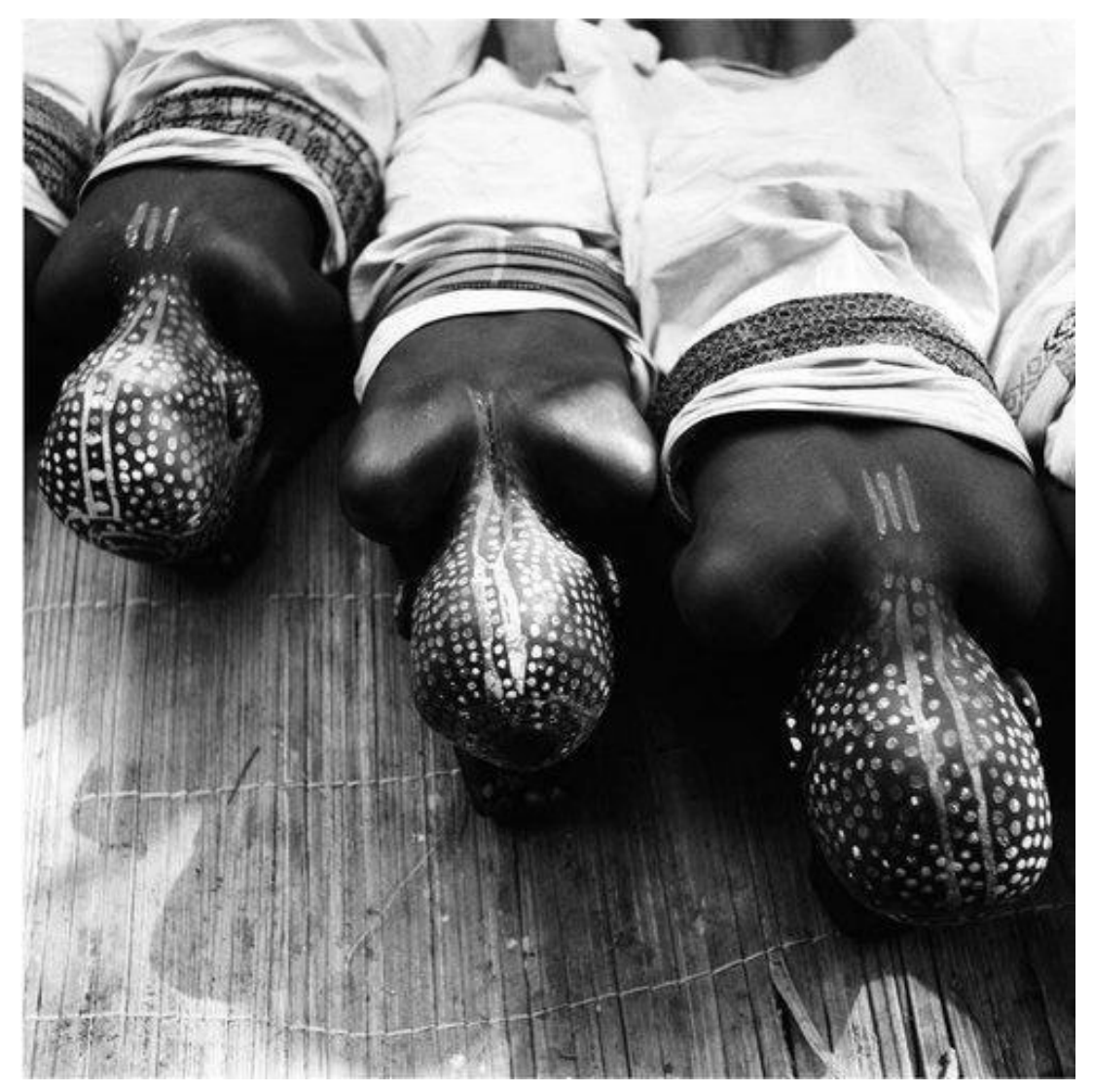

Fig. 2 - Cena de Iniciação, Briki, Ifanhin, Benin,1958 - FPV 5441 - Foto Pierre Verger (c Fundação Pierre Verger.

Reconhece-se na obra de Verger o ser humano como principal temática, com ênfase nas formas, possibilitada pelas oposições em tons de cinza, preto e branco, pelos contornos específicos e pela valorização da dimensão plástica (Figura 3). Verger se utiliza de recursos como o contraluz e o contre plongée (low-angle shot) ${ }^{4}$ para destacar as formas dos corpos e objetos, de modo a definir suas silhuetas e evidenciar, a partir de sua forma, o tipo de personagem fotografado.

4 um plano de ângulo baixo é um disparo de um ângulo da câmera posicionado baixo no eixo vertical, abaixo da linha dos olhos, olhando para cima. Psicologicamente, o efeito do plano de baixo ângulo é que faz o sujeito parecer forte e poderoso. 


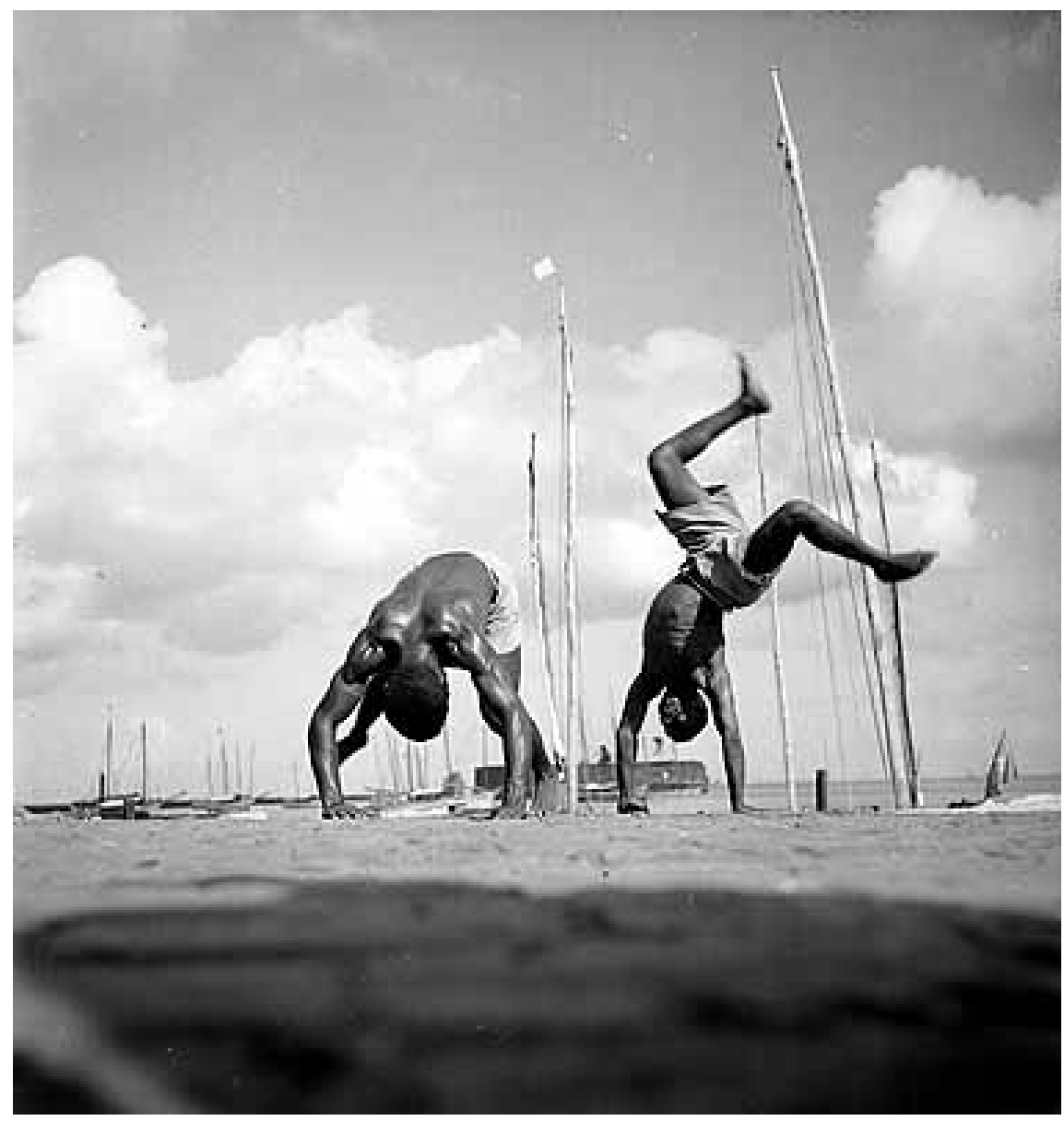

Fig. 3 - Capoeiristas na rampa do Mercado, Salvador, Brasil, 1946 - 1947, FPV 26442 - Foto Pierre Verger (c) Fundação Pierre Verger.

Ao recorrer à contraluz, o fotógrafo despreza qualquer ênfase nas expressões do rosto ou em seus aspectos fisionômicos, mas Verger deixa visível o ambiente e a ação desenvolvida pelo personagem. E o fazer na representação dos personagens se dá pelas ações que eles produzem e não somente pela sua caracterização física (Figura 4 ).

Em muitas imagens Verger tem um olhar cuidadoso em destacar as indumentárias e outros materiais como parte complementar dos caracteres pessoais e sociais. O homem visto em seu meio, através de seu meio, inserindo uma relação de equivalência entre personagem e ambiente através da contextualização dos cenários, da caracterização dos personagens, dos gestos ou das atitudes expressivas do corpo.

A intensidade do brilho na pele dos personagens é ressaltada pela presença da luz enfatizando o principal foco humano para Verger: a pele negra. As gradações da luminosidade nos corpos dos personagens faz ressaltar a imagem em seu aspecto de plasticidade. Ao observador parece possível sentir a intensidade do calor do sol sobre a pele. Porém, este brilho na pele não parece indicativo de suor, mas parece inerente ao próprio corpo do personagem, como um tipo de pele que brilha naturalmente (Figura 5). 


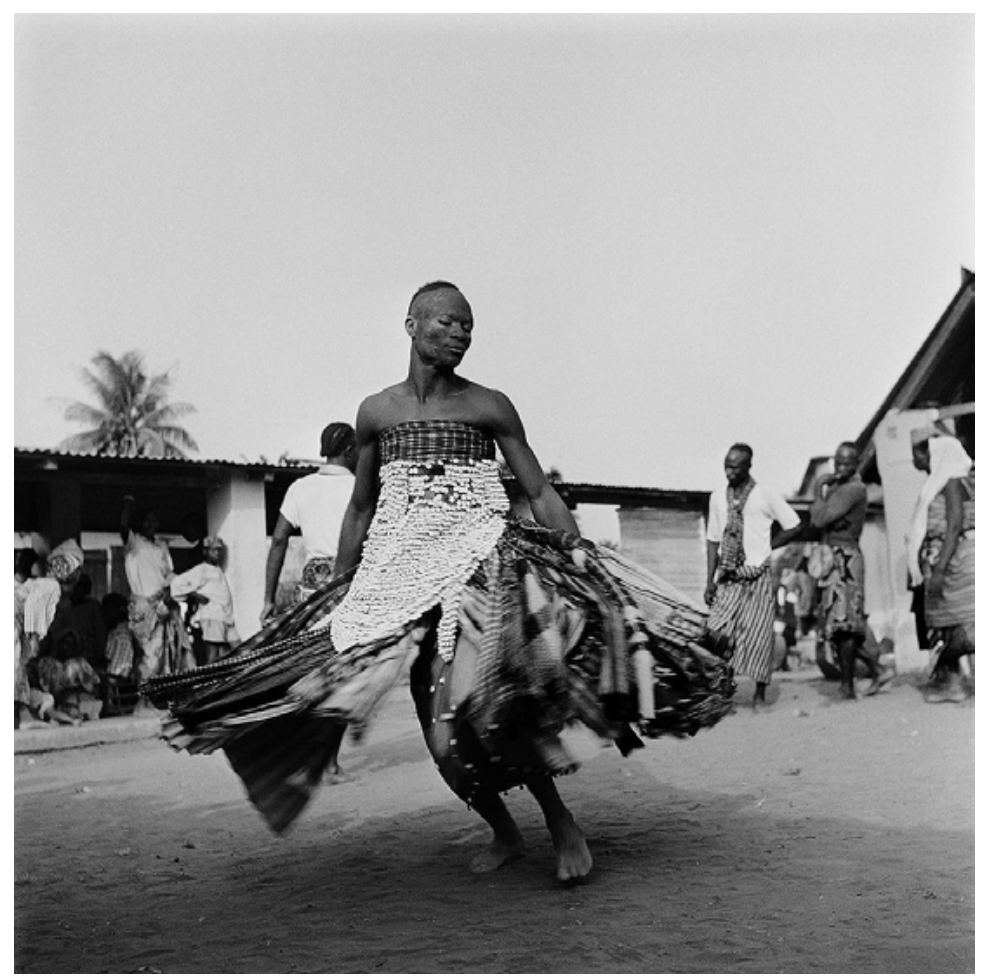

Fig. 4 - Dança de Xangô, Ifanhin, Benin, Africa - Anos 50 - FPV 5563 - Foto Pierre Verger (c) Fundação Pierre Verger.

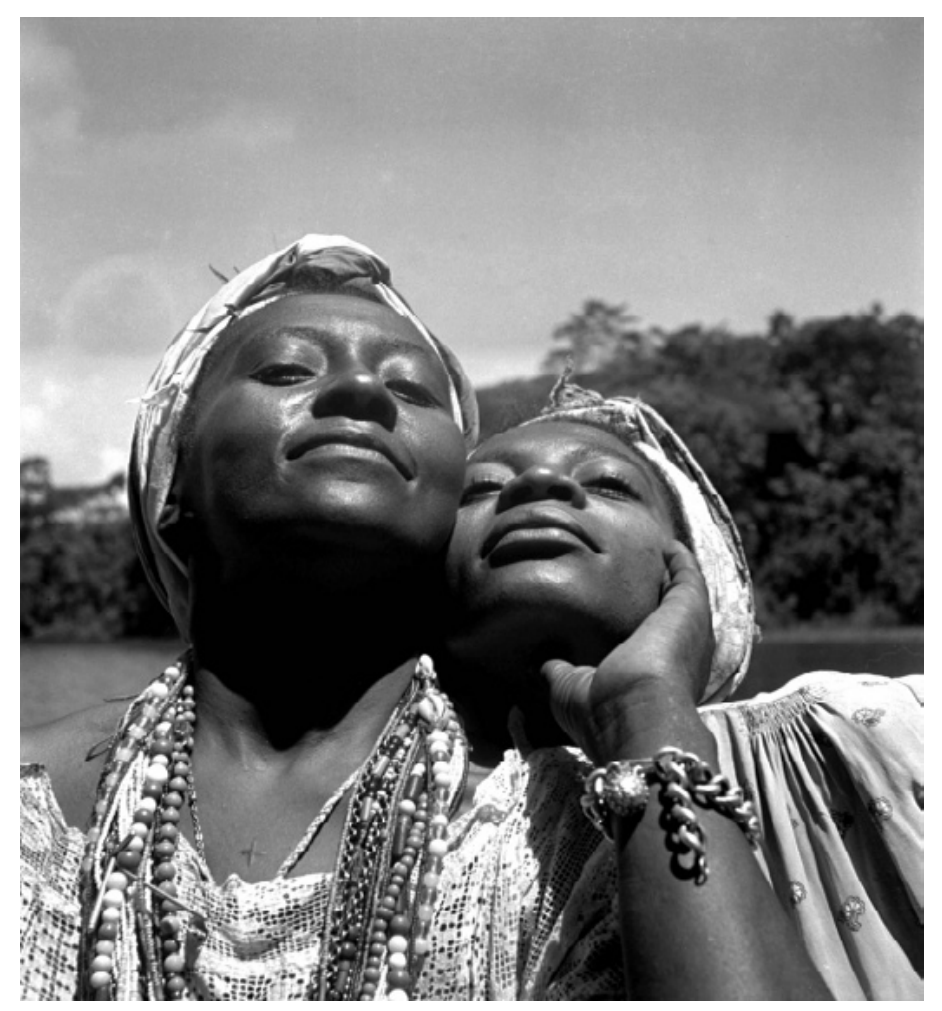

Fig. 5 - Filhas de Santo, Candomblé Joãozinho da Gomea, Salvador, Brasil,1946. FPV 27401 - Foto Pierre Verger (c) Fundação Pierre Verger. 


\section{Considerações Finais}

Finalmente, entende-se que a obra fotográfica de Verger, no que se refere ao sincretismo religioso na Bahia, dialoga perfeitamente com as relações de interterritorialidade de continentes que desenvolveram e ainda desenvolvem um processo de descolonização. O seu olhar, embora de etnia europeia, traduz esse sincretismo nas imagens capturadas nos rituais do candomblé da Bahia e da África, não apenas como fotógrafo, mas principalmente como participante ativo desses rituais. É essa imersão que nos fornece a compreensão do ser "pessoa afro-diaspórica", em especial naqueles afrodescendentes do território da Bahia.

\section{Referências}

DANTAS, Carolina Vianna. Mobilização negra nas primeiras décadas republicanas. In: Hebe Mattos, Martha Abreu (orgs.). O negro no Brasil: Trajetórias e lutas em dez aulas de história. Rio de Janeiro. Objetiva, 2012. p. 85 - 98.

GAGLIANONE, Isabela. Pierre Verger, "50 anos de fotografia 1932-1982. O Benedito: Resenhas e ensaios literário-filosóficos. Fotografia, Resenhas. Marcado com a tag Pierre Verger, em 03/09/2014. 2014. Disponível em: <https://obenedito.com.br/pierre-verger-50anos-fotografia/>. Acesso em: 29 nov. 2020.

GATTI, José. Dialogismo e sincretismo: (re)definições. Bakhtiniana, Rev. Estud. Discurso, São Paulo, v.11, no 3, p.59-79, dez, 2016. Disponível em: <http://www.scielo.br/scielo. php?script=sci_arttext\&pid=S2176-45732016000300059\&lng=pt\&nrm=iso >. Acesso em: 29 nov. 2020.

GOMES, Laurentino. Escravidão: do primeiro leilão de cativos em Portugal até a morte de Zumbi dos Palmares. 1ª. Edição. Rio de Janeiro. Globo Livros. 2019. 479 p.

GÓMEZ Pedro Pablo, MIGNOLO, Walter. Estéticas decoloniales. Sentir, pensar, hacer en abya yala y la gran comarca [recurso electrónico] https://adelajusic.files.wordpress. com/2012/10/decolonial-aesthetics.pdf. Bogotá: Universidad Distrital Francisco José de Caldas. 2012. 92p.

HALL, Stuart. Cultural identity and cinematic representation. Framework: The Journal of Cinema and Media. London, n. 36, 1989, p. 68-82. Disponível em: <https://www.jstor.org/ stable/44111666>. Acesso em: 20 abr. 2019.

LÜHNING, Angela. Pierre Fatumbi Verger e sua obra. Afro-Asia, Salvador, n. 21-22 (19981999), p.315-364. Disponível em: <https://portalseer.ufba.br/index.php/afroasia/article/ view/20971/13574>. Acesso em: 29 jul. 2019. 
MALDONADO-TORRES, Nelson. El arte como territorio de re-existencia: una aproximación decolonial. Iberoamérica Social: revista-Red de estudios sociales VIII: 26-28. 2017. Disponível em: <http:// iberoamericasocial.com/arte-territorio-re-existencia-una-aproximaciondecolonial>. Acesso em: 29 nov. 2020

MARTINI, Gerlaine Torres. A fotografia como instrumento de pesquisa na obra de Pierre Fatumbi Verger. 1999. Dissertação de Mestrado. Progr. Pós-graduação, Faculdade de Comunicação. Universidade de Brasília. Brasilia. 1999. 184pp

MUNANGA, Kabengele. Entrevista de Kabengele Munanga - A difícil tarefa de definir quem é negro no Brasil. Estudos Avançados, São Paulo, Universidade de São Paulo, no 18 (50), p. 51-56, 2004. Disponível em: <http://www.scielo.br/pdf/ea/v18n50/a05v1850.pdf>. Acesso em: 18 jul. 2019.

MUNANGA, Kabengele. Kabengele Munanga, 2000. Arte afro-brasileira. O que é afinal? In: Histórias afro-atlânticas (vol 2) Antologia. PEDROSA, Adriano, CARNEIRO, Amanda, MESQUITA, André (organização editorial). São Paulo: MASP. 624 p. 2018. p 113 - 124

QUINTERO Pablo, FIGUEIRA Patricia, ELIZALDE, Paz Concha. Uma breve história dos estudos decoloniais. 2019. MASP Afterall. Arte e descolonização. Disponível em: <https:// masp.org.br/uploads/temp/temp-6b4An9oil56DP0KVnRBC.pdf>. Acesso em: 09 jul. 2019.

SONTAG, Susan. Sobre a fotografia. Tradução Rubens Figueiredo. 1a. Edição. São Paulo. 10a. Impressão. Companhia das Letras, 2004. 223 p.

SOUTY, Jérôme. Em busca do olhar virgem: a propósito das fotografias de Pierre-Verger em torno do mundo, 1932-1946. Revista Poiésis, Niterói, Rio de Janeiro. no 12, p.209-221. 2008. Disponível em: <https://periodicos.uff.br/poiesis/article/view/26975>. Acesso em: 18 jul. 2019.

TAVARES, Luís Henrique Dias. História da Bahia. Editora UNESP. Salvador, Bahia. 10ª Edição (revista e ampliada). 2001.542p.

WOLFENSON, Bob. Bob Wolfenson: cartas a um jovem fotógrafo. O mundo através das lentes. Rio de Janeiro: Elsevier, 2009. 223 pp. 